\title{
Evaluating the Antifungal Activity of Some Traditional Medicinal Plant Extracts against Alternaria solani (Tomato Early Blight Pathogen) in Ethiopia
}

\author{
Meseret Tadelo1, Tamirat Wato², Tilahun Negash²
}

10.18805/ag.DF-407

\begin{abstract}
Background: Tomato (Lycopersicon esculentum Mill.) belongs to the family Solanaceae. In Ethiopia, control of early blight is largely dependent on fungicidal application. There is a research need to identify effective botanical extracts to control Alternaria solani that cause early blight of tomato and for evaluation of plant extracts through different solvents on the target pathogen.

Methods: In vitro experiment was conducted to evaluate the effectiveness of crude extracts of 16 selected medicinal plants against Alternaria solani. Thus, crude extracts were extracted from medicinal plants with different solvents (methanol, ethanol and petroleum at $(25 \%, 50 \%$ and $100 \%)$ concentrations. The Alternaria solani was isolated from infected tomato leaves showing early blight symptoms. Evaluation of plant extracts was carried out against Alternaria solani using food poisoned technique on PDA.

Result: Results showed that most of the methanolic extract plants were showed significant inhibition of the mycelial growth as compared to ethanolic and petroleum ether extracts. A higher rate of mycelial reduction was recorded by ethanol extracts of Allium sativum at all concentrations (100\%) followed by methanol extracts of Allium sativum at $25 \%, 50 \%, 100 \%$ concentration (90.02\%, $97.01 \%, 100 \%$ respectively). The effectiveness of extracts against Alternaria solani depends on use at the higher concentrations and various solvents. For crude extracts that have shown higher inhibitory effects against Alternaria solani in vitro conditions, actual chemical compounds should be identified. Furthermore, it is also important to evaluate these plants on other microbes, study to test in vivo and to assess their real potential field condition wherever early blight is an important disease of tomato.
\end{abstract}

Key words: Alternaria solani, Disease intensity, In vitro test, Lycopersicon esculentum, Medicinal plants.

\section{INTRODUCTION}

Tomato (Lycopersicon esculentum Mill.) belongs to the family Solanaceae (Isah et al. 2014). In Ethiopia tomato is one of the most important and widely grown vegetable crops, both during the rainy and dry seasons for its fruit by smallholder farmers, commercial state and private farms (Ambecha et al. 2012; Emana et al. 2014; Ketema et al. 2015; Tsehaye et al. 2020). The total production of tomato in Ethiopia has shown a marked increase since it became the most profitable crop providing a higher income to small-scale farmers compared to other vegetable crops (Lemma 2002; Desta and Yesuf 2015). The national average yield of tomatoes in Ethiopia is very low which is around 9.3 tons/ha and less than $50 \%$ of the current world average yield of about 27 tons/ha (CSA 2017).

Tomato production and productivity are very low due to many biotic and abiotic factors. Among biotic factors, early blight caused by Alternaria solani (Ellis and Martin) is the important foliage and fruit disease causing yield losses of about $79 \%$ in the world and $53 \%$ in Ethiopia (Chaerani and Voorrips 2006; Somappa et al. 2013; Desta and Yesuf 2015). Alternaria solani is a soil-inhabiting air-borne pathogen responsible for leaf blight, stem collar, fruit rot and can damage during all stages of plant development disseminated by fungal spores (Abada et al. 2008; Creswell 2014; Desta and Yesuf 2015)
1Department of Plant Science, College of Agriculture and Environmental Sciences, Debark University, P.O. Box 90, Debark, N/Gondar, Ethiopia.

${ }^{2}$ Department of Plant Science, College of Agriculture and Natural Resource, Bonga University, P.O. Box 334, Bonga, Ethiopia.

Corresponding Author: Tilahun Negash, Department of Plant Science, College of Agriculture and Natural Resource, Bonga University, P.O. Box 334, Bonga, Ethiopia. Email: tilatanejash211@gmail.com

How to cite this article: Tadelo, M., Wato, T. and Negash, T. (2022). Evaluating the Antifungal Activity of Some Traditional Medicinal Plant Extracts against Alternaria solani (Tomato Early Blight Pathogen) in Ethiopia. Agricultural Science Digest. DOI: 10.18805/ ag.DF-407.

Submitted: 20-09-2021 Accepted: 16-12-2021 Online: 16-01-2022

In Ethiopia, control of early blight is largely dependent on fungicidal application. Because of the polycyclic nature of the disease, several applications of fungicides are required to offer an adequate protection of the tomatoes from early blight attacks.

However, the application of fungicide is generally associated with issues of environmental pollution, high production costs (Abuley et al. 2018) and the risk of fungicide resistance that may arise due to excessive application of fungicides (Abdel-fattah et al. 2011; Alwathnani and Perveen 2012). 
The use of resistant cultivars in the control of early blight offers an economical and environmentally friendly alternative consistent with the objective of integrated pest management (Abuley et al. 2018). Unfortunately, no tomato cultivar has been reported to be completely resistant to early blight in Ethiopia (Holley et al. 1983; Ainhoa 2016). Because of the continued cultivation of tomatoes in major growing areas of Ethiopia, early blight is a constant threat throughout the year. Recent efforts have focused on developing environmentally safe, long-lasting and effective biocontrol methods for the management of plant diseases (Meena et al. 2021). So, plant products (botanicals) are used as an alternative to synthetic chemicals as they are cheap, non-photo toxic, systemic, environmentally friendly and necessary to minimize these diseases.

They are easily biodegradable, hence considered safe for the environment and human health compared to synthetic fungicides and cheaper (Koul 2008; Nerio et al. 2010 and Gurjar et al. 2012). Plant extracts are important sources of antimicrobial products for the available new chemotherapeutic agent of the control plant diseases (Mousavi et al. 2009; Safaray et al. 2009). Several plant products have shown antimicrobial activity against fungal pathogens under in vitro and in vivo conditions (Abo-Elyousr and Nashwa 2012; Bahraminejad et al. 2015; Ahmad et al. 2017). Among these, plant extract has proved effective in inhibiting the growth and reproduction of fungal plant diseases like Alternaria solani. Parthenium hysterophorus, Vernonia amygdalina, Eucalyptus camaldulensis, Nerium oleander, Lantana camara and Ocimum sanctum (Singh et al. 2014); Pongamia piñata, Aegle marmelos, Azadirachta indica, Brassica campestris, Piper nigrum, Euphorbia tirucalli, Vitex negundu, Ageratum conyzoides, Tagetes patula and Zigiphus jujube (Pattnaik et al. 2012); Ocimum tenuiflorum, Azadirachta indica, Pongamia pinnata, Datura stramonium, Withania somnifera, Calotropis gigantia, Allium crispum, Lepidium sativum and Mentha requienii (Sahu et al. 2014); garlic extracts (Abo-Elyousr and Nashwa 2012); Eucalyptus globules (Patel and Jasrai 2015) were shown to have inhibitory activity against different plant pathogens.

There is no scientific study conducted and no efforts have been made to utilize locally available botanicals for the control of Alternaria solani causative agents of early blight of tomato in Ethiopia. There is a research need to identify effective botanical extracts to control Alternaria solani that cause early blight of tomato and for evaluation of plant extracts through different solvents on the target pathogen. Therefore, the study was undertaken with the following specific objectives.

$>$ To evaluate the efficacy of different plant extracts against Alternaria solani in vitro conditions.

$>$ To determine the yield of the crude extracts of antifungal compounds from medicinal plants by using different solvents.

\section{MATERIALS AND METHODS}

An experiment was conducted Haramaya University, Ethiopia in the Laboratory of Plant Pathology for evaluating the antifungal activity of traditional medicinal plant extracts with different solvents at three concentration levels.

\section{Collection of plant materials}

Samples of fresh plant materials with potential antifungal activity were collected from the South-Eastern part of Ethiopia based on previous reports on their antifungal activity and traditional knowledge in the societies (Table 1). These plant materials have been published by many reports on the antimicrobial activity of plant extracts. Collected plant materials were identified at Addis Ababa University National Herbarium, Ethiopia. The collected plant materials were washed with tap water and air-dried under shade (Baris et al. 2006) to a constant weight. The dried plant was chopped and ground to a fine powder using a coffee grinder and stored in a sealed plastic bag at room temperature until needed.

\section{Treatment and experimental design}

The experiment was arranged in a factorial randomized complete design (CRD) combination of 16 plant material $x$ 3 solvents (ethanol, methanol and petroleum) with three concentrations $(25 \%, 50 \%$ and $100 \%)$ in three replications positive and negative control was including.

\section{Isolation and identification of the pathogen}

Diseased tomato leaves showing typical symptoms of early blight were collected. The infected leaf parts were cut into small pieces and surface sterilized with 0.1 percent mercuric chloride $\left(\mathrm{HgCl}_{2}\right)$ solution for 30 seconds and washed three times with distilled water, then cultured on Potato Dextrose Agar (PDA) and incubated at $25^{\circ} \mathrm{C}$ for 3 days. The cultured fungus was observed under microscopy and identified based on morphological features of the colony, spore characteristics and referring the relevant literature. Pure culture of the pathogen was maintained on PDA Petri plates at $4{ }^{\circ} \mathrm{C}$. Pathogenicity test was done by spray method under greenhouse conditions (Simmsons 2007).

\section{Preparation of plant extracts}

Fifty grams of each powdered material were macerated separately in $250 \mathrm{ml}$ of (ethanol, methanol and petroleum ether) contained in a sterile conical flask covered with cotton wool plug and wrapped with aluminum foil (Kulkarni et al. 2011). The extraction was done using an electrical flask shaker at maximum speed (300rpm) with continuous shaking for $48 \mathrm{hrs}$. The extracts were taken out by filtering using a clean muslin cloth (Wokocha and Okereke 2005) followed by filtration using a Whatman number 1 filter paper to avoid a fibrous portion of the plant completely (Bekele et al. 2015). The debris was discarded while the filtrate was transferred to an evaporating dish and kept in a dry oven at $30^{\circ} \mathrm{C}-40^{\circ} \mathrm{C}$ until the extract materials were concentrated. The extracts were then stored in air-tight bottles at $4{ }^{\circ} \mathrm{C}$ in a refrigerator until use in bioassay (Naduagu et al. 2008). Finally, the gram yield of the dried residue of each plant extracts was calculated using the formula (Kigondu et al. 2009). 
Evaluating the Antifungal Activity of Some Traditional Medicinal Plant Extracts against Alternaria solani (Tomato Early Blight...

Percentage yield $(\%)=\frac{\text { Weight of extract }}{\text { Weight of plant material }} \times 100$

In vitro evaluation of efficacy plant extracts against Alternaria solani

Different concentrations of the extracts were prepared by diluting the crude extracts with Dimethyl Sulfoxide (DMSO) to get $25 \%, 50 \%$ and $100 \%$ concentration. One $\mathrm{ml}$ of the different concentrations from each plant extract (i.e., stock solution) was mixed thoroughly in melted serialized PDA $(18 \mathrm{ml})$ medium in a serialized conical flask, just before pouring in sterilized $9 \mathrm{~cm}$ diameter Petri plates. Then after solidification, $6 \mathrm{~mm}$ diameter of actively growing mycelium disc from seven days old culture of the test pathogen by the help of sterilized cork borer was placed at the center of medium and three replications were maintained for each treatment. Plates containing PDA medium with fungicide tilt $(25 \%, 50 \%$ and $100 \%)$ served as a positive control and plates with medium added with distilled water served as negative controls. The plates were then sealed with Parafilm and incubated at $25^{\circ} \mathrm{C}$; three replicates were maintained for each treatment. The mycelia growth was recorded six days after inoculation. The experiments were repeated twice and the mean of readings was taken for calculations. The inhibitory activity of each treatment was expressed as the percent growth inhibition as compared to the negative control (0\%) using the following (Pandey et al. 1982).

$$
\text { Growth inhibition }(\%)=\frac{D C-D T}{D C} \times 100
$$

Where

$\mathrm{DC}=$ Diameter mycelium growth of fungus $(\mathrm{mm})$ in control, DT = Diameter mycelium growth of fungus $(\mathrm{mm})$ in treatment

\section{Data analysis}

The data collected were subjected to analysis of variance (ANOVA) using Statistical Analysis System (SAS) version
9.2 Software. The mean comparison of different treatments was performed using Tukey's post-test at $\mathrm{P} \leq 0.05$ level of significance.

\section{RESULTS AND DISCUSSION}

\section{Percentage yield of plant extract}

The extracts obtained by using three solvents were compared for the efficiency of eluting solvents by calculating the percentage yield of extracted materials. In methanol extract, the maximum yield was from Eucalyptus globules (44.92\%) followed by Vernonia amygdalina (40.52\%), Ricinus communis (36.76\%), Solanum nigrum (29\%) and Solanum incanum (29\%), However, Allium cepa (9.36\%) and Allium sativum $(9.36 \%)$ gave the least amount of yield as compared to other extracts. In ethanol extract, the maximum yield was due to Eucalyptus globules (36.1\%) followed by Hagenia abyssinica (28.28\%), Ricinus communis (27.40\%), Vernonia amygdalina $(26.76 \%)$ and Zehneria scabra $(22.44 \%)$. The least amount of yield plant extract was recorded from Rumex nepalensis (9.24\%). Using petroleum as solvent of extraction, the highest yield was obtained from Eucalyptus globules (20.38\%), Justicia schim (15.46\%), Coriandrum sativum (8.86\%), Hagenia abyssinica (7.32\%) and Rumex nepalensis $(7.06 \%)$. The lowest percentage yields recorded were the petroleum extract of the Melia azedarach $(3.64 \%)$ (Table 2$)$.

\section{Efficacy test of the plant extracts on Alternaria solani disease}

The effect of interaction among sixteen medicinal plant extracts was studied by using three solvents at three levels of concentrations in the laboratory (Fig 1-3) against Alternaria solani showed significant $(P<0.001)$ variation on the percent of growth inhibition (Table 3 ). In this investigation, the inhibitory activity of the methanol, ethanol and petroleum ether extracts at the three concentrations $(25 \%, 50 \%$ and

Table 1: Botanicals and their parts used in the experiment.

\begin{tabular}{lcccc}
\hline Scientific name & Common name & Family & Local name & Plant parts \\
\hline Allium cepa & Onion & Alliaceae & Key shinkurt & Bulb \\
Allium sativum & Garlic & Amaryllidaceae & Nech shinkurt & Bulb \\
Coriandrum sativum & Coriander & Apiaceae & Dimbilal & Fruit \\
Eucalptues globules & Eucalptues & Alliaceae & Bahirzaf & Leaf \\
Justicia schim Periana & & Acanthaceae & Smiza & Leaf \\
Hagenia abyssinica. & Hagenia & Rosaceae & Kosso & Leaves \\
Malva parviflora & & Malvaceae & Lenkuata & Leaf \\
Melia azedarach & Chinaberry & Meliaceae & Neem & Leaf \\
Ricinus communis & Castor & Euphorbiaceae & Yegulo zeyit & Leaf \\
Rumex abyssinicus & Spinach Rhubarb & Polygonaceae & Mokemoko & Leaf \\
Rumex nepalensis & Sorrel & Polygonaceae & Tult & Leaf \\
Rumex nervosus & & Polygonaceae & Ambacho & Leaf \\
Solanum incanum & Solanaceae & Embuay & Leaf \\
Solanum nigrum & Sodom apple & Solanaceae & Alumina & Leaf \\
Vernonia amygdalina & Black nightshade & Asteraceae & Girawa & Leaf \\
Zehneria scabra & Bitter leaf & Cucurbitaceae & Aregeressa & Leaf \\
\hline
\end{tabular}


Evaluating the Antifungal Activity of Some Traditional Medicinal Plant Extracts against Alternaria solani (Tomato Early Blight...

Table 2: The percentage yield of plant extracts using methanol, ethanol and petroleum.

\begin{tabular}{|c|c|c|c|c|c|c|c|c|}
\hline \multirow[b]{2}{*}{ Medicinal plant species } & \multirow{2}{*}{$\begin{array}{c}\text { Plant } \\
\text { part used }\end{array}$} & \multirow{2}{*}{$\begin{array}{l}\text { Weight of } \\
\text { sample (g) }\end{array}$} & \multicolumn{3}{|c|}{ The dry weight of the extract } & \multicolumn{3}{|c|}{ Percentage yields (\%) of extracts } \\
\hline & & & Methanol & Ethanol & Petroleum & Methanol & Ethanol & Petroleum \\
\hline Melia azedarach & Leaf & 50 & 16.72 & 12.75 & 3.64 & $16.72 \%$ & $12.75 \%$ & $3.64 \%$ \\
\hline Zehneria scabra & Leaf & 50 & 27.00 & 22.44 & 4.60 & $27.00 \%$ & $22.44 \%$ & $4.60 \%$ \\
\hline Rumex nepalensis & Leaf & 50 & 13.24 & 9.24 & 7.06 & $13.24 \%$ & $9.24 \%$ & $7.06 \%$ \\
\hline Solanum incanum & Leaf & 50 & 29.00 & 13.34 & 5.40 & $29.00 \%$ & $13.34 \%$ & $5.40 \%$ \\
\hline Coriandrum sativum & Seed & 50 & 16.94 & 16.18 & 8.86 & $16.94 \%$ & $16.18 \%$ & $8.86 \%$ \\
\hline Rumex abyssinicus & Leaf & 50 & 16.14 & 13.56 & 5.54 & $16.14 \%$ & $13.56 \%$ & $5.54 \%$ \\
\hline Solanum nigrum & Leaf & 50 & 29.00 & 13.34 & 5.40 & $29.00 \%$ & $13.34 \%$ & $5.40 \%$ \\
\hline Justicia schim & Leaf & 50 & 20.98 & 13.68 & 15.46 & $20.98 \%$ & $13.68 \%$ & $15.46 \%$ \\
\hline Allium sativum & Bulb & 50 & 9.36 & 21.62 & 5.80 & $9.36 \%$ & $21.62 \%$ & $5.80 \%$ \\
\hline Malva parviflora & Leaf & 50 & 20.22 & 15.50 & 4.14 & $20.22 \%$ & $15.50 \%$ & $4.14 \%$ \\
\hline Hagenia abyssinica & Leaf & 50 & 15.90 & 28.28 & 7.32 & $15.90 \%$ & $28.28 \%$ & $7.32 \%$ \\
\hline Eucalyptus globules & Leaf & 50 & 44.92 & 36.10 & 20.38 & $44.92 \%$ & $36.10 \%$ & $20.38 \%$ \\
\hline Vernonia amygdalina & Leaf & 50 & 40.52 & 26.76 & 6.36 & $40.52 \%$ & $26.76 \%$ & $6.36 \%$ \\
\hline Allium сера & Bulb & 50 & 9.36 & 21.62 & 5.80 & $9.36 \%$ & $21.62 \%$ & $5.80 \%$ \\
\hline Rumex nervosus & Leaf & 50 & 27.64 & 21.56 & 5.60 & $27.64 \%$ & $21.56 \%$ & $5.60 \%$ \\
\hline Ricinus communis & Leaf & 50 & 36.76 & 27.40 & 6.46 & $36.76 \%$ & $27.40 \%$ & $6.46 \%$ \\
\hline
\end{tabular}

Table 3: ANOVA table for mycelia growth inhibition from plates treated with different extracts of respective plant species with solvents and concentrations at different days after inoculation.

\begin{tabular}{|c|c|c|c|c|c|c|}
\hline \multirow{2}{*}{ Sources } & \multirow{2}{*}{ Df } & \multicolumn{5}{|c|}{ Mean squares } \\
\hline & & $6 \mathrm{DAl}$ & $7 \mathrm{DAl}$ & 8 DAI & $9 \mathrm{DAl}$ & $10 \mathrm{DAl}$ \\
\hline Bot & 15 & $16210.23^{* * *}$ & $917.38^{* * *}$ & $1450.16^{* * *}$ & $1167.91^{\text {***}}$ & $951.98^{* * *}$ \\
\hline Sol & 2 & $27544.89^{* * *}$ & $11084.88^{* * *}$ & $13772.44^{* * *}$ & $18726.13^{\star * *}$ & $17108.16^{\star * *}$ \\
\hline Con & 2 & $6376.96^{* * *}$ & $3358.85^{\star \star \star}$ & $3188.48^{* \star *}$ & $3036.90^{* * *}$ & $3249.87^{\star * *}$ \\
\hline Bot*Sol & 30 & $58156.36^{\star \star *}$ & $1870.89^{* * *}$ & $1938.54^{* * *}$ & $2128.91^{* * *}$ & $1988.4^{\star * *}$ \\
\hline Sol ${ }^{*}$ Con & 4 & $111.89^{\star \star *}$ & $69.2^{\star * *}$ & $27.97^{\star \star \star}$ & $15.09^{\star \star \star}$ & $9.58^{* *}$ \\
\hline Bot $^{*}$ Con & 30 & $1195.53^{* * *}$ & $49.32^{* * *}$ & $39.85^{\star * *}$ & $53.44^{* * *}$ & $35.74^{* * *}$ \\
\hline Bot $^{*}$ Sol ${ }^{*}$ Con & 60 & $2221.32^{* * *}$ & $52.01^{* * *}$ & $39.85^{\star * *}$ & $32.17^{\star \star *}$ & $27.69^{* \star *}$ \\
\hline Error & & 3.64 & 7.12 & 3.64 & 2.64 & 1.85 \\
\hline CV & & 3.19 & 4.33 & 3.19 & 2.81 & 2.33 \\
\hline R2 & & 99.14 & 98.17 & 99.14 & 99.45 & 99.57 \\
\hline
\end{tabular}

$\mathrm{DAI}=$ Days after inoculation, $\mathrm{DF}=$ degree of freedom, Bot= botanical, Sol $=$ solvent, $\mathrm{Con}=$ concentration, $\mathrm{CV}=$ Coefficient of variation, ${ }^{* *}$ Very highly significant, $(\mathrm{P}<0.001){ }^{* *}$ highly significant, $\mathrm{R} 2=$ coefficient of determination.

$100 \%)$ showed significant different $(P<0.05)$ variations in the degree of inhibitory activity against Alternaria solani as compared to the negative control. However, none of the treatments except ethanol extract of Allium sativum (25\%, $50 \%$ and with methanol extract $(100 \%)$ was unequally inhibited the mycelial growth of Alternaria solani to that of positive control (tilt). The extract of Allium sativum with ethanol at all concentrations and with methanol extract at $(100 \%)$ was completely inhibited against radial growth mycelium as compared to a positive control (Table 4).

In the present finding, methanol extracts were showed the highest percentage growth inhibition zone at $100 \%$ was recorded from Allium sativum (100\%) followed by Allium cepa (82.39\%), Vernonia amygdalina $(81.44 \%)$, Ricinus communis (81.16\%) and Eucalyptus globules (80.68\%), while at the lowest percentage growth inhibition zone was recorded from methanol extracts of Rumix nepalensis
(64.96\%). At $50 \%$ concentration, Allium sativum, Vernonia amygdalina and Eucalyptus globules resulted in a higher rate of reduction of mycelial growth of $A$.solani in the percentage of $(97.01 \%),(80.11 \%)$ and $(79.55 \%)$ respectively be an effective zone of inhibition at as compared to the other treatments. Allium sativum (90.02), Vernonia amygdalina (78.98\%), Hagenia abyssinica (75.38\%) and Allium cepa $(75 \%)$ indicated the highest inhibition zone among methanol extracts at $25 \%$ of concentration level. Although the difference between Allium cepa and Hagenia abyssinica was not significantly varied $(P>0.05)$. Similarly, the lowest percentage growth inhibition zone was recorded from methanol extracts Rumex nepalensis (49.43\%) at a concentration level of $25 \%$ (Table 4 ).

From our result, the antimicrobial activity of the ethanol extracts at $100 \%$ concentration was showed the highest percent mycelial growth inhibition was recorded by Allium 
sativum (100\%), followed by Ricinus communis $(71.59 \%)$, Rumex nervosus (59.85\%) and Allium cepa (57.20\%). The lowest percentage growth inhibition zone was recorded by Solanum incanum (37.69\%) followed by Rumex abyssinicus $(39.39 \%)$, but it was significantly $(P<0.05)$. The ethanol extract at $50 \%$ concentration produced the highest percent growth inhibition by Allium sativum (100\%), Eucalyptus globules $(81.82 \%)$ and Rumex nervosus $(55.87 \%)$. The lowest percentage growth inhibition zone was recorded from Coriander sativum (34.66\%) and Solanum incanum (35.04\%) at a concentration of $50 \%$. At $25 \%$ concentration, the highest mycelial inhibition of Alternaria solani was recorded from the ethanol extracts of Allium sativum (100\%), Eucalyptus globules (79.73\%) and Allium cepa (49.43\%) against Alternaria solani. The ethanol extract showed less effective inhibition zone Coriandrum sativum (28.79\%) and Rumex nepalensis (28.41\%) at a concentration level of $25 \%$ (Table 4 ).

The petroleum ether extracts at $100 \%$ concentration showed significantly varied effects on mycelial growth inhibition of $A$. solani (Fig 3 ). Among the various plant extracts, Solanum incanum was recorded the highest percentage of growth inhibition (86.82\%) followed by Rumex nervous $(83.52 \%)$, Malva parviflora $(81.82 \%)$ and Melia azedarach $(80.68 \%)$ at $100 \%$ concentration while the lowest percentage mycelial growth inhibition zone was observed from petroleum ether extracts Eucalyptus globules (40.15\%), Allium sativum (44.67\%) and Hagenia abyssinica (50.95\%) at a concentration of $100 \%$. At $50 \%$ concentration, the petroleum ether extracts of Rumex nervous (81.44\%), Malva parviflora $(79.73 \%)$ and Melia azedarach $(78.41 \%)$ displayed a higher rate of mycelial inhibition over all the other extracts. The least inhibition of mycelial growth of $A$. solani was recorded in Eucalyptus globules (34.47\%) followed by Hagenia abyssinica (44.13) at 50\% percent concentration. The petroleum ether extracts of Malva parviflora $(76.70 \%)$, Rumex nervous (76.14\%) and Melia azedarach (75.76\%) were found to be best in inhibiting the mycelial growth of $A$. solani at $25 \%$ concentration. The lowest percentage growth inhibition zone was recorded from extracts Eucalyptus globules (27.65\%) followed by Hagenia abyssinica (36.74\%) at a concentration of $25 \%$ (Table 4 ).

For each medicinal plant extract, the highest rate of radial mycelial growth inhibition was recorded in a higher concentration level. Overall, the highest rate mycelial inhibition was recorded by ethanol extract of Allium sativum, followed by methanol extract with Allium sativum and petroleum extract of Solanum incanum (Table 2).

Tomato (Solanum lycopersicum Mill.) belongs to the family Solanaceae and is the world's largest important vegetable crop after potato. Tomato is known as a productive as well as protective food. Tomato production and productivity are very low due to a lack of proper disease, insect pest management and other agronomic practices (Fig 4).

Various results of yield extracts were obtained from different plant materials with different solvents. Most methanol extracts give maximum yields followed by ethanol,

Table 4: Effect of sixteen medicinal plant extracts were studied by using three solvents at three levels of concentrations.

\begin{tabular}{|c|c|c|c|c|c|c|c|c|c|}
\hline & \multicolumn{8}{|c|}{ Per cent inhibition of mycelia growth (\%) 10 days after inoculation } & \\
\hline & \multicolumn{2}{|c|}{ Methanol extracts } & \multicolumn{2}{|c|}{ Ethanol extracts } & \multirow[b]{2}{*}{$50 \%$} & \multicolumn{4}{|c|}{ Petroleum ether extracts } \\
\hline & $25 \%$ & $50 \%$ & $100 \%$ & $25 \%$ & & $100 \%$ & $25 \%$ & $50 \%$ & $100 \%$ \\
\hline Zehneria scabra & $68.75^{\mathrm{GFE}}$ & $71.4^{\mathrm{FEGD}}$ & $75.76^{\mathrm{FE}}$ & $30.87^{1 \mathrm{~J}}$ & $37.12^{\mathrm{HGI}}$ & $41.48^{\mathrm{ILKJ}}$ & $52.84^{\mathrm{DC}}$ & $57.58^{\mathrm{C}}$ & $59.85^{c}$ \\
\hline Rumex nepalensis & $49.43^{\mathrm{GH}}$ & $53.98^{\mathrm{HG}}$ & $64.96^{\mathrm{FHG}}$ & $28.41^{\mathrm{J}}$ & $39.39^{\mathrm{G}}$ & $45.46^{1 \mathrm{H}}$ & $45.1^{\mathrm{HG}}$ & $53.79^{\mathrm{DE}}$ & $57^{\mathrm{DFCE}}$ \\
\hline Melia azedarach & $71.59^{\mathrm{DFE}}$ & $77.7^{\mathrm{CBD}}$ & $78.41^{\mathrm{CED}}$ & $32.95^{1 \mathrm{H}}$ & $39.02^{G}$ & $43.18^{\mathrm{LKJ}}$ & $75.76^{B}$ & $78.41^{\mathrm{B}}$ & $80.68^{\mathrm{B}}$ \\
\hline Solanum incanum & $66.01^{\mathrm{GF}}$ & $72.92^{\mathrm{FCED}}$ & $73.86^{\mathrm{FHG}}$ & $33.71^{\mathrm{H}}$ & $35.04^{\prime}$ & $37.69^{\llcorner}$ & $49.1^{\mathrm{FE}}$ & $53.79^{\mathrm{DE}}$ & $86.82^{\mathrm{DFCE}}$ \\
\hline Coriandrum sativum & $68.18^{\mathrm{GFE}}$ & $69.13^{\mathrm{FG}}$ & $73.67^{\mathrm{FHG}}$ & $28.79^{\lrcorner}$ & $34.66^{\mathrm{HI}}$ & $44.89^{1 \mathrm{HJ}}$ & $46.78^{\mathrm{FG}}$ & $51.14^{\mathrm{FE}}$ & $54.55^{\mathrm{FGE}}$ \\
\hline Rumex abyssinicus & $54.17^{I J}$ & $69.51^{\text {CEBD }}$ & $75.57^{\mathrm{FEG}}$ & $32.39^{1 \mathrm{H}}$ & $37.50^{\mathrm{HGI}}$ & $39.39^{\mathrm{LK}}$ & $54.55^{\mathrm{C}}$ & $56.82^{\mathrm{DC}}$ & $57.95^{\mathrm{DCE}}$ \\
\hline Solanum nigrum & $73.3^{\mathrm{DCE}}$ & $74.05^{\mathrm{GEFD}}$ & $76.33^{\mathrm{FED}}$ & $38.83^{\mathrm{GF}}$ & $45.664^{\mathrm{FE}}$ & $54.55^{\mathrm{EF}}$ & $50.76^{\mathrm{DE}}$ & $55.11^{\mathrm{DC}}$ & $56.82^{\mathrm{DFCE}}$ \\
\hline Justicia schim & $57.56^{\prime}$ & $62.12^{\mathrm{H}}$ & $71.78^{\mathrm{HG}}$ & $36.74^{\mathrm{G}}$ & $38.83^{\mathrm{HG}}$ & $48.11^{\mathrm{GH}}$ & $45.83^{\mathrm{HG}}$ & $47.92^{\mathrm{FGH}}$ & $53.98^{\mathrm{FG}}$ \\
\hline Allium sativum & $90^{\mathrm{B}}$ & $97^{\mathrm{A}}$ & $100^{A}$ & $100^{A}$ & $100^{A}$ & $100^{\mathrm{A}}$ & $42.61^{\mathrm{H}}$ & $44.70^{1 \mathrm{H}}$ & $44.67^{\mathrm{H}}$ \\
\hline Malva parviflora & $58.9^{1 \mathrm{H}}$ & $60.99^{H}$ & $71.59^{\mathrm{H}}$ & $40.91^{\mathrm{F}}$ & $43.56^{\mathrm{F}}$ & $48.86^{\mathrm{GH}}$ & $76.70^{\mathrm{B}}$ & $79.73^{\mathrm{B}}$ & $81.82^{\mathrm{B}}$ \\
\hline Hagenia abyssinica & $75.38^{\mathrm{DC}}$ & $78.6^{\mathrm{CB}}$ & $79.92^{\mathrm{CBD}}$ & $37.31^{\mathrm{G}}$ & $39.21^{\mathrm{G}}$ & $40.91^{\text {LKJ }}$ & $36.74^{\prime}$ & $44.13^{\prime}$ & $50.95^{\prime}$ \\
\hline Eucalyptus globules & $72.73^{\mathrm{DE}}$ & $79.55^{\mathrm{B}}$ & $80.68^{\mathrm{CB}}$ & $79.73^{\mathrm{B}}$ & $81.82^{\mathrm{B}}$ & $83.14^{\mathrm{B}}$ & $27.65^{\mathrm{J}}$ & $34.47^{\lrcorner}$ & $40.15^{1}$ \\
\hline Vernonia amygdalina & $78.98^{\mathrm{C}}$ & $80.11^{\mathrm{B}}$ & $81.44^{\mathrm{CB}}$ & $46.59^{\mathrm{D}}$ & $48.86^{\mathrm{DE}}$ & $50.76^{\mathrm{GF}}$ & $42.80^{\mathrm{H}}$ & $47.54^{\mathrm{GH}}$ & $57^{\mathrm{DFCE}}$ \\
\hline Allium cepa & $75^{\mathrm{DC}}$ & $79.17^{\text {Св }}$ & $82.39^{\mathrm{B}}$ & $49.43^{c}$ & $52.27^{\mathrm{DC}}$ & $57.20^{\mathrm{ED}}$ & $47.35^{\mathrm{FEG}}$ & $54.55^{\mathrm{DC}}$ & $59.09 \mathrm{DC}$ \\
\hline Rumex nervosus & $63.83^{\prime}$ & $66.29^{\prime}$ & $73.49^{\prime}$ & $43.75^{\mathrm{E}}$ & $55.87^{\mathrm{C}}$ & $59.85^{\mathrm{D}}$ & $76.14^{\mathrm{B}}$ & $81.44^{\mathrm{B}}$ & $83.52^{\mathrm{B}}$ \\
\hline Ricinus communis & $55.68^{\prime}$ & $75.76^{\text {CEBD }}$ & $81.16^{\mathrm{CB}}$ & $48.30^{\mathrm{DC}}$ & $50.39^{\mathrm{D}}$ & $71.59^{\mathrm{C}}$ & $44.70^{\mathrm{HG}}$ & $48.86^{\mathrm{H}}$ & $56.1^{\mathrm{FG}}$ \\
\hline $\mathrm{NC}$ & $0^{\mathrm{K}}$ & $0^{J}$ & $0^{J}$ & $0^{\mathrm{K}}$ & $0^{J}$ & $0^{\mathrm{M}}$ & $0^{\mathrm{K}}$ & $0^{\mathrm{K}}$ & $0^{\mathrm{J}}$ \\
\hline PC & $100^{A}$ & $100^{A}$ & $100^{A}$ & $100^{A}$ & $100^{\mathrm{A}}$ & $100^{\mathrm{A}}$ & $100^{\mathrm{A}}$ & $100^{A}$ & $100^{A}$ \\
\hline Tukey's (0.05) & 2.27 & 3.11 & 2.19 & 1.4 & 2.1 & 2.2 & 1.93 & 1.8 & 1.99 \\
\hline CV $(\%)$ & 2.15 & 2.75 & 1.8 & 1.9 & 2.5 & 2.5 & 2.28 & 1.97 & 2.04 \\
\hline
\end{tabular}

NC: Negative control; PC: Positive control; CV: Coefficient of variability. 


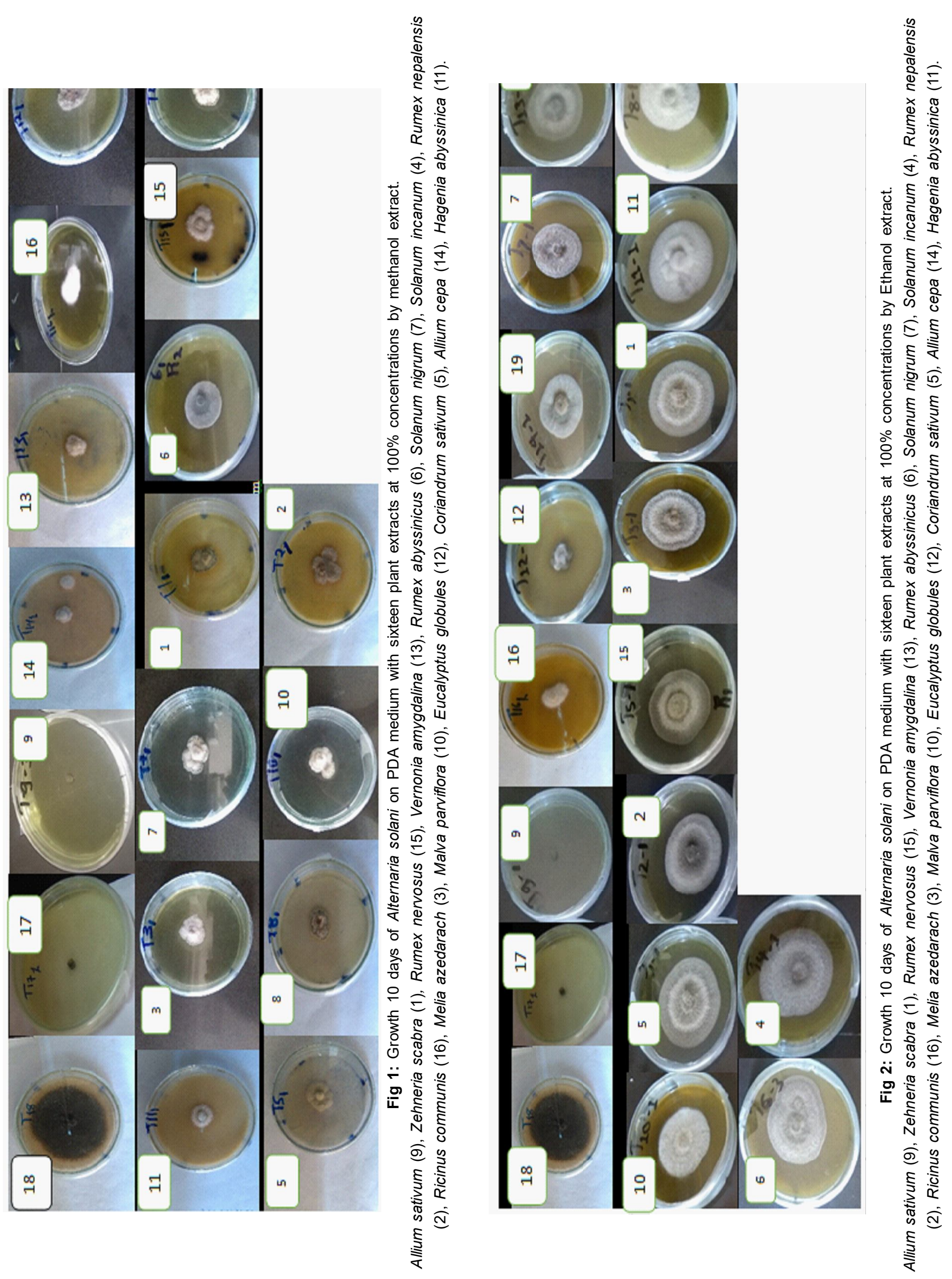



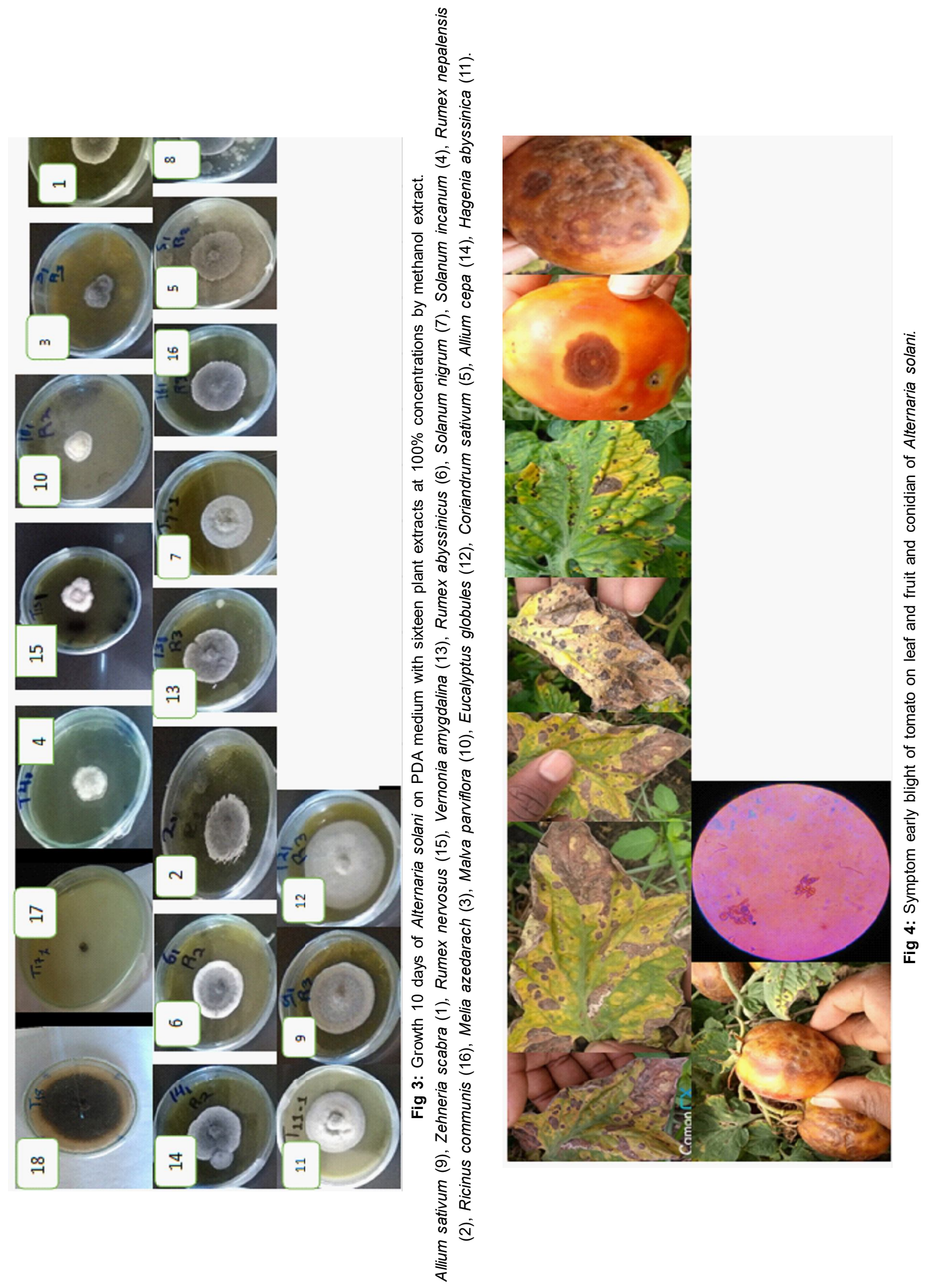
while the minimum amount was obtained from petroleum ether extract. The percentage yield of the methanol extracts of Eucalyptus globules was obtained maximum yield followed by Vernonia amygdalina by three different solvents the minimum yield was recorded from petroleum ether extract. The previous work also studies (Djelloul et al. 2017) recorded that extracts of Eucalyptus globules with petroleum ether solvents were obtained maximum yield than Rosmarinus officinalis plant. The maximum gram yield of Hagenia abyssinica extracted was found to be in the order of ethanol, methanol and petroleum ether. However, opposite results were reported by Tesfaye et al. (2016) who recorded maximum yield found to be in the order of methanol, petroleum ether and ethanol.

The maximum amount of gram yield was obtained extracted increased from non-polar to polar solvents. The present study correlated with the previous studies, methanol extracts are higher solubility of extractable bioactive components to remaining used the other solvents (Dhawan and Gupta 2017). Petroleum ether is non-polar while methanol and ethanol are polar compounds. The efficiency of methanol was related to intermediate polarity its strong antimicrobial activity (Augusto et al. 2014; Nguyen et al. 2015). The yield of methanol extraction increases alongside the solubility of antimicrobial plant components increases (Merveill et al. 2017). Several workers have reported that a wide range of significant differences for the yields could be due to various factors such as time of extraction, type and part of plant materials used, extraction of solvent polarities, fineness of powder and extent of dryness (Maharjan et al. 2010; Ngeny 2012; Silva et al. 2014; Naima et al. 2015; Arakaki et al. 2016; Felhi et al. 2017).

The efficacy of the sixteen plant extracts against the tomato early blight fungi was tested in vitro. The results showed that the extracts exhibited significantly $(P<0.05)$ a varied percentage of inhibition of the mycelia growth of the fungal pathogens at three concentrations with three solvents tested. The maximum mycelial inhibition was recorded at $100 \%$ concentration while the lowest inhibition was at $25 \%$ concentration. Our results were similarly correlated works Abo-Elyousr et al. (2012) and Hubert et al. (2015) who reported that the effects of plant extracts increased with an increasing amount of concentration.

The present study showed that among sixteen plants most of the methanol extracts displayed higher antifungal activity against mycelium growth of Alternaria solani as compared to ethanol and petroleum ether extract. This agrees with the finding of some workers who reported that the methanol extracts for all of the tested plants showed significant antimicrobial activities against $E$. coli compared to the activity of the other solvents such as diethyl ether, ethyl acetate and chloroform, N- butanol, diethyl-ether, ethyl acetate (El Sayed and Aly 2014; Hussein 2016).

Ethanol extract of Allium sativum was highly preventing against mycelia growth of Alternaria solani in order of ethanol $>$ methanol $>$ Petroleum Ether extract. Closely in agreement with our study Hajano et al. (2012) showed the extraction of garlic bulb was completely inhibitory against tested $M$. oryzae. The ethanol extract of $A$. sativum was the most effective plant that reduced the radial growth of Colletotrichum kahawae (Amsalu et al. 2011). The finding was also following Sesan et al. (2017) who reported that Allium sativum was the greatest inhibitory activity among nine plant species against Fusarium oxysporum. The use of Allium sativum has a great potential in suppressing several plant pathogenic fungi (Amin et al. 2009; Charimbu et al. 2009; Panchal and Patil 2009; Su and Cheng et al. 2008; Taskeen-Un-Nisa et al. 2011; Amsalu et al. 2011). The present finding of this study compares to other studies to become sometimes contrary for our study when used common materials that same plants may have different antimicrobial activity in same solvents on different organisms or same organisms. These reasons may be due to different extraction procedures used from one author to another author (Nasim et al. 2012).

A methanol extract of Solanum incanum was showed a higher degree of inhibition against Alternaria solani pathogen followed by petroleum ether and ethanol extracts. However, at a concentration of $100 \%$, the PE of Solanum incanum exhibited the highest percentage of inhibition as compared to the methanol and ethanol extracts. A similar result was obtained by some workers; methanolic extract of Solanum incanum has better antimicrobial activity on E.colli (Hussein 2016). Ethanol extract of fruit Solanum incanum gives higher inhibition against pathogenic bacteria and fungus (Indhumathi and Mohandass 2014; Kipngeno et al. 2014). In our study, the ethanol extract of Eucalyptus globules exhibited higher antifungal activity compared to methanol and petroleum ether. Previous research work revealed that Eucalyptus globules leaf from methanol extracts was effective to inhibit the growth of Alternaria brassicae in vitro conditions (Ramezani and Mohammad 2015). Antifungal properties of Eucalyptus globules ethanol extracts against gladiolus wilt at different concentration was highly appreciated (Jan et al., 2015).

The results obtained from methanol extracts of Allium cepa were a more inhibitory effect compared to the other two solvents. Alcohol extract of onion and garlic bulb extract showed the highest inhibition of Alternaria alternata growth at both $5 \%$ and $10 \%$ concentrations (Sanjeev et al. 2017). Aqueous extract of Allium cepa also inhibited against Fusarium solani (Ahmed et al. 2012), F. oxysporum f. sp. Gladioli (Chohan et al. 2011; Parvu and Parvu 2011).

The previous studies indicated that medicinal plants have different antimicrobial activities depending on extraction solvent, plant types and amount of the presence of bioactive compound (Sequeira et al. 2013; Stankovi et al. 2015; Bahraminejad et al. 2015; Arakaki et al. 2016). These plants have huge availability nearly our village and easy preparation method can be used by farmers. Among plant extracts, ethanol and methanol extract of Allium sativum was found highly effective in reducing the mycelial growth of 
Alternaria solani as a positive control of tilt fungicide. Many researchers had also shown that the most potent antimicrobial activity by mostly total inhibition and intermediate inhibition.

\section{CONCLUSION AND RECOMMENDATION}

Tomato (Solanum lycopersicum Mill.) belongs to the family Solanaceae and is the world's largest important vegetable crop after potato. Tomato production and productivity are very low due to a lack of proper disease and insect pest management and other agronomic practices. Early blight of tomato is the most economically important disease was found widely distributed in all the surveyed areas. The findings of the present study indicated that early blight of tomato incidence and severity varies among districts, date of planting, crop density, weed management and environmental factors. The present study revealed that proper weeding practices, optimum plant density, crop rotation with non-solanaceous plants and other related farm practices should be carried out to reduce the yield loss of tomatoes due to early blight in the surveyed area. Moreover, extensive studies are required to investigate whether Amaranthus hybridus, Datura stramonium, Commelina bengnalensis, Cyperus esculentus, Ipomea ariocarpa and Chenopodium procerum weeds are an alternative hosts for the early blight of tomato.

Since the study was additional in vitro experiments, this investigation demonstrates the potentials medicinal plants as potential alternatives to fungicides in the control of early blight of tomato. Our results revealed that most methanolic extracts showed significant inhibition of the mycelial growth of the test plant pathogen as compared to ethanolic and petroleum ether extracts. The Ethanol extract of Allium sativum at all concentrations and methanol extract at $100 \%$ concentration showed the complete reduction of the mycelial growth of Alternaria solani. The finding of this investigation suggested that the same plants have different antimicrobial activity in different solvents. Even if the rate of inhibition differed from one extract to the other, our results showed that the extracts of all evaluated solvents (methanol, ethanol and petroleum ether) were significantly inhibited the mycelia growth of the Alternaria solani at all different concentrations compared to untreated control.

Plant extracts were highly recommended for use at the higher concentrations in controlling Alternaria solani, the causative agent of early blight of tomato since they are locally available. The results of this study are also important steps towards developing natural plant-based fungicides which are eco-friendly for the management of early blight of tomato for the development of commercial formulations of botanicals. Allium sativum has a strong pungency smell and is volatile so that it can be kept away from the garden pest. The higher amount of gram yield was obtained extracted increase with increasing polarity. For crude extracts that have shown higher inhibitory effects against Alternaria solani in vitro conditions, their actual chemical compounds identified should be further studied to in vivo conditions. Furthermore, it is also important to evaluate these plants on other microbes and to assess their real potential field conditions wherever early blight is an important disease of tomatoes.

\section{AKNOWLEDGEMENT}

I express my heartfelt gratitude to Dr. Hassen Shifa and Dr. Adissu Assefa for their guidance, unfailing support and professional expertise in bringing this work to completion.

\section{REFERENCES}

Abada, K.A., Mostafa, S.H., Hillal, M.R. (2008). Effect of some chemical salt son suppressing the infection by early blight disease of tomato. Egypt J. of Applied Sci. 23: 47-58.

Abdel-Fattah, G.M., El-Haddad, S.A., Hafez, E.E., Rashad, Y.M. (2011). Induction of defense responses in common bean plants by arbuscular mycorrhizal fungi. $\mathrm{J}$ of Microbiol Res. 166(4): 268-281.

Abo-Elyousr, K.A.M., Nashwa, S.M.A. (2012). Evaluation of various plant extracts against the early blight disease of tomato plants under greenhouse and field conditions. Plant Prot Sci. 48: 74-79.

Abuley, I.K., Nielsen, B.J., Labouriau, R. (2018). Resistance status of cultivated potatoes to early blight (Alternaria solani) in Denmark. Plant Pathol. 67: 315-326. Doi: 10.1111/ppa.12744.

Ahmad, F., Raziq, F., Ullah, N., Khan, H., Din, N. (2017). In vitro and in vivo bio-assay of phytobiocidal effect of plant extracts on Alternaria solani causing agent of early blight disease in tomato. Archives of Phytopathol and Plant Prot. 50(11-12): 568-583.

Ahmed, S., Zaman, N., Khan, S.N. (2012). Management of root rot disease of groundnut (Arachis hypogeae L.) by plant extracts. African J. of Microbiol Res. 6(21): 4489-4494.

Ainhoa, M.M. (2016). Tomato plants are more resistant against nematodes when colonized by a fungus. Retrieved 9 March 2021 from https://phys.org/news/2016-11-tomatoresistant-nematodescolonized-fungus.html.

Alwathnani, H.A., Perveen, K. (2012). Biological control of fusarium wilts of tomato by antagonist fungi and cyanobacteria. African J. of Biotechnol. 11(5): 1100-1105.

Ambecha, O., Gemechis Paul, C., Struik Bezabih, E., (2012). Tomato production in Ethiopia: Constraints and Ppportunities. Corpus ID: 171087714.

Amin, A.B.M.R., Rashid, M.M., Meah, M.B. (2009). Efficacy of garlic tablet to control seed born fungal pathogens of cucumber. J. of Agricultut Rural Dev't. 7: 135-138.

Amsalu, A., Fikre, L., Diriba, M. (2011). The antifungal activity of some medicinal plants against coffee berry disease caused by Colletotrichum kahawae. Inter J. of Agricultur. Res. 6: 268-279. DOI: 10.3923/ijar.2011.268.279

Arakaki, D.G., Candido, C.J., Silva, A.F.D., Guimarães, R.D.C.A., Hiane, D.A. (2016). In vitro and in vivo antioxidant activity of the pulp of Jatobá-do-cerrado. Food Sci. and Technol (Campinas.). 36(1): 166-170.

Augusto, T.R., Salinas, E.S.S., Alencar, S.M., D arce, M.A.B.R., Camargo, A.C., Vieira, T.M.F.S. (2014). Phenolic compound and antioxidant activity of hydroalcoholic extracts of wild and cultivated murtilla (Ugni molinae Turcz.). Food Sci and Technol (Campinas.). 34(4): 667-673. 
Bahraminejad, S., Amiri, R., Abbasid, S. (2015). Anti-fungal properties of 43 plant species against Alternaria solani and Botrytis cinerea. Arch of Phytopathol and Plant Protect. 48(4): 336-344.

Baris, O., Gulluce, M., Sahin, F., Ozer, H., Kilic, H., Ozkan, H. (2006). Biological activities of the essential oil and methanol extract of Achillea Biebersteinii Afan. (Asteraceae). Turkey J. Biol. 30: 65-73.

Bekele, A., Rahel, A., Taye, M. (2015). Antimicrobial activity of Thymu schimperi against standard and clinical isolates of human pathogenic bacteria. $\mathrm{J}$ of Medicinal Plants Res. 9(11): 379-384.

Chaerani, R., Voorrips, R.E. (2006). Tomato early blight (Alternaria solani). The pathogen, genetics and breeding for resistance. J. of Genet and Plant Pathol. 72: 335-347.

Charimbu, M.K., Wagara, L.N., Otaye, D.O. (2009). Antifungal activity of various plant extract against Phaeoisariopsis griseola pathogenic on common bean. African Crop Sci Confer Proceed. 9: 683-685.

Chohan, S., Atiq, R., Mehmood, M.A., Naz, S., Siddique, B., Yasmin, G. (2011). Efficacy of few plant extracts against Fusarium oxysporum f. sp. gladioli, the cause of corm rot of gladiolus. J of Medicin Plant Res. 5 (16): 3887-3890.

Creswell, T. (2014). Alternaria solani (Early blight of tomato). Purdue University.

CSA (Central Statistical Agency). 2017. The Federal Democratic Republic of Ethiopia Agricultural sample survey for 2017 report. Central Statistical Agency, Addis Ababa, Ethiopia.

Desta, M., Yesuf, M. (2015). Efficacy and economics of fungicides and their application schedule for early blight (Alternaria solani) management and yield of tomato at South Tigray, Ethiopia. J. Plant Pathol Microb. 6: 268. doi:10.4172/ 2157-7471.1000268

Dhawan, D., Gupta, J. (2017). Comparison of different solvents for phytochemical extraction potential from Datura metel plant leaves. Inter J. of Biol Chem. 11: 17-22.

Djelloul, R., Mokrani, K., Hacini, N. (2017). Study of the antibacterial activity of the extract from the essential oil of Eucalyptus globulus and Rosmarinus officinalis on three bacterial strains. Inter J. of Appl Environ Sci. 12(1): 47-56.

El Sayed, H., El Sayed, A., Aly, M.M. (2014). Antibacterial activities of six medicinal plants. NMJ. 3(13): 27-37.

Emana, B., Ayana, A., Balemi, T., Temesgen, M. (2014). Scoping study on vegetables seed systems and policy in Ethiopia. Final Report. Asian Veget Res and Dev't Cent, Shanhua, Taiwan.

Felhi, S., Daoud, A., Hajlaoui, H., Mnafgui, K., Gharsallah, N., Kadri, A. (2017). Solvent extraction effects on phytochemical Constituents profiles, antioxidant and antimicrobial activities and functional group analysis of Ecballium elaterium seeds and peels fruits. Food Sci and Technol Campinas. 37(3): 483-492.

Gurjar, M.S., Ali, A.M., Singh, K.S. (2012). Efficacy of plant extracts in plant disease management. Agricult Sci. 3(3): 425-433.

Hajano, J., Lodhi, A.M., Pathan, M.A., Khanzada, M.A., Shah, G.S. (2012). In vitro evaluation of fungicides, plant extracts and bio-control agents against rice blast pathogen Magnaporthe oryzaecouch. Pakistan J. of Botanist. 44: 1775-1778.
Holley, J.H., Hall, R., Hofstra, G. (1983). Identification of rate-reducing resistance to early blight in potato. Canadian J. of Plant Pathol. 2: 111-114 DOI: 10.1080/07060668309501637.

Hubert, J., Matagalpa, R.B., Mamiro, D.P. (2015). Efficacy of selected plant extracts against Pyricularia grisea, Causal agent of rice blast disease. American J. of Plant Sci. 6: 602-611.

Hussein, D., Alkhalifah, M. (2016). Antimicrobial activities of Solanum incanum, Elettaria cardamomum and Zingiber officinale, used traditionally to treat pathogenic microbes. Inter J. of Sci Engi and Applied Sci. 2(3).

Indhumathi, T., Mohandas, S. (2014). Efficacy of ethanolic extract of Solanum incanum fruit extract for its antimicrobial activity. Inter J. of Curr. Microbiol and Applied Sci. 3(6): 939-949.

Isah, A.S., Amans, E.B., Odion, E.C., Yusuf, A.A. (2014). Growth rate and yield of two tomato varieties (Lycopersicon esculentum Mill) under green manure and npk fertilizer rate Samaru Northern Guinea Savanna. Inter J of Agron, 1-4. https://doi.org/10.1155/2014/932759.

Jan, O., Ganie, S.A., Pant, V.R., Ghani, M.Y., Lone, A.H., Razvi, S.M., Anjum, Q. (2015). In vitro evaluation of some plant extracts, fungal antagonists and organic amendments against Fusarium oxysporum f. sp. gladioli causing gladiolus wilt. Inter J. of Modern Biol and Medic. 6(2): 107-117.

Ketema, B., Derbew, B., Jima, N. (2015). Evaluation of tomato (Lycopersicon esculentum Mill.) varieties for seed yield and yield components under Jimma Condition, South Western Ethiopia. J of Agron. 14: 292-297. DOI: 10.3923/ ja.2015.292.297 URL: https://scialert.net/abstract/?doi =ja.2015.292.297

Kigondu, E.V.M., Rukunga, G.M., Keriko, J.M., Tonui, W.K., Gathirwa, J.W., Kirira, P.G., Irungu, B., Ingonga, J.M., Ndiege, I.O. (2009). Anti-parasitic activity and cytotoxicity of selected medicinal plants from Kenya. J of Ethnopharmacol. 123: 504-509.

Kipngeno, C.D., Mshimba, S.M., Gilbert, C., John, A.O. (2014). Antimicrobial activity and phytochemical investigation of crude extracts of the fruits of Solanum incanum (Solananceae) and Dovyalis abbysinica (Flacourtiaceae). Science Journal of Microbiology.

Koul, O. (2008). Phytochemical and insect control: an antifeedant approach. Crit. Rev. of Plant Sci. 27: 1-24.

Kulkarni, S., Khatwani, P. (2011). Optimization of extraction conditions and development of a sensitive. Inter J. of Pharmaceut Sciand Drug Res. 3(1): 56-61.

Lemma, D. (2002). Tomatoes; research experiences and production prospects. EARO, Report No. 43. Addis Ababa, Ethiopia.

Maharjan, B.L., Shrestha, K., Basnyat, S. (2010). Botanical control of late blight of potato. Nepal J. of Sci and Technol. 11: 37-40.

Meena, B.R., Meena, S., Chittora, D., Sharma, K. (2021). Antifungal efficacy of Thevetia peruviana leaf extract against Alternaria solani and characterization of novel inhibitory compounds by Gas Chromatography-Mass Spectrometry analysis. Biochem Biophys Rep.; 25: 100914. doi: 10.10 16/j.bbrep.2021.100914. 
Merveille, T.O., Denis, Z., Abde, N.J., Ursula, A.A., Fleury, A.A., Adie, M., Smith, B.B., Zipoh, N.A., Joseph, Y.N., Peter, N.F., Veronique, P.B., Clement, A.N.J. (2017). Antimicrobial activities of some medicinal plants against multi resistants microorganisms causing urogenital tract infections in Cameroon. J. of Diseases and Medicin Plants. 3(2): 33-41.

Mousavi, S.M., Mirzargar, H.E.Z., Mousavi. R.O., Baigi, A., Khosravi, A., Bahonara, M.R., Ahmadi, S.S. (2009). Evaluation of antifungal activity of new combined essential oils in comparison with malachite green on hatching rate in rain bow trout (Oncorhynchus mykiss) eggs. J of fisher and Aquatic Sci. 4: 103-110.

Naduagu, C., Ekefan, E.J., Nwankiti, A.O. (2008). Effect of some crude plant extracts on growth of Colletotrichum capsici (Synd) butler and Bisby causal agent of pepper anthracnose. J. of Appli Biosci. 6: 184-190.

Naima, R., Oumam, M., Hannache, H., Sesbou, A., Charrier, B., Pizzi, A., Charrier-El, B.F. (2015). Comparison of the impact of different extraction methods on polyphenols yields and tannins extracted from Moroccan Acacia mollissima barks. Industr Crops and Products. 70: 245-252.

Nasim, F.H. andleeb, S., Iqbal, M., Ghous, T., Nisar, K.A., Akhtar, K. (2012). Evaluation of antimicrobial activity of extracts of fresh and spoiled Spinacia oleracea against some mammalian pathogens. African J. of Microbiol Res. 6: 5851-47.

Nerio, L.S., Olivero-Verbel, J., Stashenko, E. (2010). Repellent activity of essential oils: A review. Bioresource Technology. 101: 372-378.

Ngeny, L.C. (2012). Evaluation of antimicrobial activity and toxicity of crude extracts from selected Kenyan medicinal plants. MSc Thesis. Jomo Kenyatta University, Kenyatta.

Nguyen, V.T., Bowyer, M.C., Vuong, Q.V., Altena, I.A.V., Scarlett, C.J. (2015). Phytochemicals and antioxidant capacity of Xao tam phan (Paramignya trimera) root as affected by various solvents and extraction methods. Industr Crops and Products. 67:192-200.

Panchal, D.G., Patil, R.K. (2009). Eco-friendly management of fruit rot of tomato caused by Alternaria alternata. J. of Mycologic Plant Pathol. 39(1): 66.69.

Pandey, D.K., Tripathi, N.N., Tripathi, R.O., Dixit, S.N. (1982). Fungitoxic and phyototoxic properties of essential oil of Phylissauvolensis. Pfkrankh Pfschuz. 89: 334-346.

Parvu, M., Parvu. A. (2011). Antifungal Plant Extracts. In: Science against Microbial Pathogens: Communicating Current Research and Technological Advances. Méndez-Vilas, A. (ed.). Formatex, Microbiology Series. 3(1).

Patel, R.M., Jasrai, Y.T. (2015). Antifungal potency of Eucalyptus globules Labill essential oil against important plant pathogenic fungi. J. of Microbiol. 4(1): 42-52.

Pattnaik, M.M., Kar, M., Sahu, R.K. (2012). Bioefficacy of some plant extracts on growth parameters and control of diseases in Lycopersicum esculentum. Asian J. of Plant Sci and Res. 2(2): 129-142.

Ramezani, H., Abdollahi, M. (2015). Management of Alternaria brassicae through some plants extract. Inter J. of Pure and Appl Biosci. 3(2): 108-112.
Safaray, A.H., Motamedi, S.M., Seyyednejad, S.M. (2009). Preliminary study on the antimicrobial activity of quercus brantii against bacterial pathogens, particularly enteric pathogens. Inter J. of Bot. 5: 176-180.

Sahu, D.K., Khare, C.P., Patel, R. (2014). Eco friendly management of early blight of tomato using botanical plant extracts. J of Industr Pollut Contr. 30(2): 215-218.

Sanjeev, P., Jakatimath, R.K., Mesta, B.B., Sadanand, K., Mushrif Ajjappalavar, P.S. (2017). In vitro evaluation of fungicides, botanicals and bio-agents against Alternaria alternata causal agent of Fruit rot of Brinjal. Inter J. of Curr Microbiol and Appl Sci. 6(5): 495-504.

SAS Institute Inc. (2008). SAS/STAT Guide for Personal Computers, version $9.2 \mathrm{E}^{\mathrm{dn}}$., SAS Institute.

Sequeira, B.J., Vital, M.J., Pohlit, A.M., Pararols, I.C., Caúper, G.S. (2013). Antibacterial and antifungal activity of extracts and exudates of the Amazonian medicinal tree Himatanthus articulatus (Vahl) Woodson (common name: sucuba). Memories Do Instituto Oswaldo Cruz. 104: 659-661.

Sesan, T.E., Elena, E., lacomi, B.M., Oprea, M., Oancea, F., lacomi, C. (2017). In vitro antifungal activity of some plant extracts against fusarium oxysporum in black currant (Ribes nigrum L.). Acta Scientific Pololonorum Hortorum Cultus. 16(6): 163-172.

Silva, C.P.D., Sousa, M.S.B., Siguemoto, É.S., Soares, R.A.M., Areas, J.A.G. (2014). Chemical composition and antioxidant activity of jatobá-do-cerrado (Hymenaea stigonocarpa Mart.) flour. Food Sci and Technol (Campinas.). 34(3): 597-603.

Simmsons, E.G. (2007). Alternaria An Identification Manual. CBS Fungal Biodiversity Center. Utrecht. The Netherlands. 379.

Singh, G., Gupta, S., Sharma, N. (2014). In vitro screening of selected plant extracts against Alternaria alternata. J. of Exp'tal Biol and Agricult Sci. 2320-8694.

Somappa, J., Srivastava, K., Sarma, B.K., Pal, C., Kumar, R. (2013). Studies on growth conditions of the Tomato Alternaria Leaf Spot Causing Alternaria solani L. The Bioscan. 8(1): 101-104.

Stankovi, N., Mihajilov-Krstev, Zlatkovi, B, Stankov-Jovanovi, V., Miti, V., Jovi, J. (2015). Antibacterial and antioxidant activity of traditional medicinal plants from the Balkan Peninsula Wagen. J. of Life Sci. 12.006 .

Su, L., Chenge, Z. (2008). Allium sativum extracts as a biopesticede affecting pepper blight. Inter J. of Veget Sci. 15: 13-23.

Taskeen-Un-Nisa, W.A.A., Bhat, M.Y., Pala, S.A., Mir, R.A. (2011). In vitro inhibitory effect of fungicides and botanicals on mycelial growth and spore germination of Fusarium oxysporum. J. of Biopesti. 4:53-56.

Tesfaye, W., Behailu, B., Tesfaye, H., Kassahun, T. (2016). Phytochemical analysis and antimicrobial activity of Hagenia abyssinica. Inter J. of Adv. Res. in Chem. Sci. 3(8): 1-9.

Tsehaye, K., Tekestebrhan, A., Wendwesen, T. (2020). Proportional enactment of tomato [Solanum Lycopersicum (L.) Mill] varieties under greenhouse production systems of Tigray Biotechnology Center, Ethiopia. Inter J. of Res in Agricult and Forestry. 7(6): 01-11.

Wokocha, R.C., Okereke, V.C. (2005). Fungitoxic activity of extracts of some medicinal plants on Sclerotium rolfsii causal organism of basal stem rots of tomato. J. of Plant Protect. 22: 106-111. 